\title{
Management of pemphigus
}

\section{Benjamin S. Daniel ${ }^{1,2}$ and Dedee F. Murrell ${ }^{1,3 *}$}

\author{
Addresses: ${ }^{1}$ Faculty of Medicine, University of New South Wales, High Street, Kensington, 2052, Sydney, Australia; ${ }^{2}$ Skin and Cancer Foundation \\ Victoria, Drummond Street, Carlton 3053, Melbourne, Victoria, Australia; ${ }^{3}$ Department of Dermatology, St. George Hospital, Gray Street, Kogarah 2217, \\ Sydney, Australia \\ * Corresponding author: Dedee F. Murrell (d.murrell@unsw.edu.au) \\ FI000Prime Reports 2014, 6:32 (doi:10.12703/P6-32) \\ All Fl000Prime Reports articles are distributed under the terms of the Creative Commons Attribution-Non Commercial License \\ (http://creativecommons.org/licenses/by-nc/3.0/legalcode), which permits non-commercial use, distribution, and reproduction in any medium, \\ provided the original work is properly cited. \\ The electronic version of this article is the complete one and can be found at: http://fl000.com/prime/reports/m/6/32

\begin{abstract}
Pemphigus is an autoimmune blistering disease characterized by cutaneous and mucosal blisters and erosions. Though systemic corticosteroids have been the mainstay of treatment for pemphigus over the years, more recently research has focused on steroid-sparing agents. This review looks at the commonly used steroid-sparing agents in pemphigus and the evidence from randomized controlled trials (RCTs) supporting their use.
\end{abstract}

\section{Introduction}

Pemphigus is an autoimmune blistering disease characterized by blisters and erosions on the skin or mucosal membranes or both. The two main types of pemphigus are pemphigus vulgaris (PV) and pemphigus foliaceus (PF). In most countries, PV accounts for about $70 \%$ of all cases of pemphigus, presenting with skin or mucosal symptoms or both. PF, on the other hand, accounts for about $20 \%$ of cases in most countries, where there are not endemic forms of PF, and presents only with skin manifestations [1-3].

Because pemphigus is an autoimmune disease, immunosuppressive agents have been employed to control and manage the disease. Since the advent of systemic corticosteroids, the mortality associated with pemphigus has reduced from $90 \%$ to $10 \%$ and is now usually related to complications of treatment $[4,5]$. Steroids are still the mainstay of treatment, usually used at high doses initially to get the disease under control and then in conjunction with a steroid-sparing agent for maintenance. Because of the side effects associated with long-term systemic corticosteroids such as hypertension, diabetes mellitus, osteoporosis, and ocular complications, a lot of the recent research in pemphigus has been directed at finding the optimal steroid-sparing agent.
Though many treatments have been tried in the management of pemphigus, often demonstrating clinical benefit in individual case reports and case series, the evidence supporting their use has not been confirmed in RCTs. This is due to the rarity of the disease in most countries where RCTs have been performed and difficulty in recruiting patients, resulting in underpowered studies. A recent Cochrane Review comparing treatments for pemphigus found significant heterogeneity amongst the RCTs with respect to the study designs, primary outcome measures, and therapeutic end-points. Such variation prevented the authors from performing direct comparisons and a meaningful meta-analysis $[5,6]$.

To solve this problem of variation between studies, a panel of international bullous experts convened on many occasions to form a consensus paper on the definitions of disease and therapeutic end-points for pemphigus [7]. The goal of this consensus paper was to facilitate researchers and clinicians to design studies with similar study end-points so that even if an RCT was underpowered, its data could be used in conjunction with other similar studies in a meta-analysis. It is hoped that in the coming years the RCTs will incorporate the endpoints and definitions from the consensus paper in their study designs so that meaningful comparisons and meta-analyses can be performed. 


\section{Therapies used in pemphigus Main Text}

This paper looks at the evidence from RCTs that have assessed treatments for pemphigus. As mentioned above, systemic corticosteroids are employed as first-line treatment with lower doses used as maintenance. Though higher doses $(120 \mathrm{mg} /$ day $)$ result in a more rapid control of disease than lower doses $(60 \mathrm{mg} /$ day $)$, there is no evidence that the higher doses are beneficial in the long term [8]. Therefore, it is recommended that $1 \mathrm{mg} / \mathrm{kg}$ per day be the initial dose for managing pemphigus. Steroidsparing agents are introduced immediately if safe to do so (for example, after normal results from a thiopurine s-methyltransferase [TPMT] test). Once consolidation has been achieved in accordance with the Consensus Definitions for Pemphigus [7] (that is, disease progression has been halted), a slow standardized tapering of corticosteroid is commenced over about a 4-month period, which we term the Werth taper [9]. Steroidsparing agents are employed to reduce the cumulative exposure and side effects associated with long-term steroid use. Such agents include azathioprine, mycophenolate mofetil, intravenous immunoglobulin (IVIg), rituximab, cyclophosphamide, methotrexate, and cyclosporine.

One of the main steroid-sparing agents used in PV is azathioprine. An RCT comparing a combination of prednisolone plus azathioprine to prednisolone plus placebo in 56 patients with newly diagnosed PV found no statistically significant difference between the 2 groups after 1 year of treatment. azathioprine, however, had a significant steroid-sparing effect [10]. The steroidsparing effects of adjuvants were also demonstrated in another RCT, which showed similar efficacy with azathioprine, mycophenolate mofetil (MMF), and intravenous cyclophosphamide [11]. The steroid-sparing effect was demonstrated only when all three agents were pooled together as one group.

Because of the similarities in efficacy and side effect profiles, clinicians often use azathioprine or MMF as first-line therapy. No study has been able to prove one to be more effective than the other [11-13]. Though MMF is a steroid-sparing agent that is safe and effective [14], a recent RCT was unable to demonstrate clinical benefit in adding it to steroids in terms of outcome at one year, but in subanalysis it had benefits at other time points [15]. RCTs to date have failed to show a beneficial effect of cyclosporine in the management of pemphigus. One study [16] compared cyclosporine plus steroids, cyclophosphamide plus steroids and steroids alone. Remission and relapse rates were similar in all three groups, and there was no clear benefit of using a combination treatment. In fact, they noticed more side effects in the combination groups compared with using steroids alone. Another RCT was unable to demonstrate an advantage of adding cyclosporine to systemic steroids [17].

A multicenter RCT comparing various doses of IVIg found patients treated with a higher dose of IVIg had a better outcome [18]. Patients received one of three doses: $0 \mathrm{mg} / \mathrm{kg}$ per day (placebo infusion), $200 \mathrm{mg} / \mathrm{kg}$ per day, or $400 \mathrm{mg} / \mathrm{kg}$ per day. There was a dose-response relationship with more patients benefiting from the higher dose and objectively this correlated with lower desmoglein (dsg)-1 and dsg-3 autoantibody titers. Adverse events were similar between the three groups. Another IVIg study also showed a beneficial effect in pemphigus [19]. The limitation of these studies was their short-term follow-up, so that relapse rates could be compared with other options.

Rituximab, an anti-CD20 monoclonal antibody, is effective in recalcitrant pemphigus and is typically prescribed for patients who are unable to taper steroids without flare of their disease or in patients who are still flaring despite combination therapy (steroids + steroidsparing agent). Rituximab is associated with a reduction in autoantibodies (dsg-1 and -3) and B cell depletion. It is administered $375 \mathrm{mg} / \mathrm{m}^{2}$ once/week for 4 consecutive weeks. The clinical benefits are noticed within 2 to 3 months of infusion and can last years [20]. One study found that the combination of rituximab for 3-weeks and IVIg for the fourth week followed by maintenance monthly rituximab and IVIg results in rapid clinical resolution, steroid cessation, and prolonged remission [21]. Another study found similar response and relapse rates with rituximab alone [22].

Despite case reports suggesting a potential role for cyclophosphamide in pemphigus treatment, benefits have not been reproduced in RCTs $[16,23]$, not even for cyclophosphamide with pulses of dexamethasone randomized against prednisone with azathioprine [24]. There are some issues with the design of this RCT, with modifications of the cyclophosphamide treatment arm compared with the original protocol and timing of cyclophosphamide doses and cessation of treatment.

In clinical practice, there is reservation from clinicians and patients using this medication given the potential long-term side effects of infertility, bladder cancer, and hemorrhagic cystitis, although these adverse effects have not been demonstrated in pemphigus RCTs. Nevertheless, the lack of level 1 evidence and the potential harmful side effects make cyclophosphamide a secondor third-line steroid-sparing agent. It is typically not 
considered unless alternative therapies have failed and should not be used on young patients unless they were not planning on having further children. Clinicians should also be aware of the potential cardiac adverse effects of pulsed cyclophosphamide $[25,26]$.

There are no RCTs assessing the efficacy of methotrexate. Hence, further evidence is required to attest to the benefit of this modality in treating pemphigus.

Although the long-term efficacy of many of the therapies in pemphigus has not been evaluated in studies, it has been noted that $60 \%$ of patients with severe pemphigus treated with rituximab were in long-term remission of 6 years [27]. In comparison, the remission rates for patients managed in the Ratnam 5-year study were 36\% $(4 / 11)$ with a dose of $120 \mathrm{mg} / \mathrm{kg}$ per day and $9 \%(1 / 11)$ with a starting dose of $60 \mathrm{mg} / \mathrm{kg}$ per day.

Rituximab has not been officially approved by the Food and Drug Administration or European Medicines Agency for pemphigus, although there are reports of success with its off-label use. IVIg is approved for relapsing and recalcitrant pemphigus by Medicare and the blood bank/official funding agencies of various countries and has also been approved by the Therapeutics Goods Administration in Australia.

\section{Conclusions}

Systemic corticosteroids are the mainstay of treatment for pemphigus. Much of the recent research has been assessing the efficacy of steroid-sparing agents, most commonly azathioprine, MMF, Rituximab, methotrexate, IVIg, and cyclophosphamide.

Although strong evidence in the form of RCTs is lacking, it does not mean that these systemic treatments are ineffective. Because of the rarity of the disease, studies are often underpowered and fail to demonstrate a statistically significant difference between the active and control groups. The evidence to date indicates that adding an adjuvant to steroids has a significant steroid-sparing effect, reducing the cumulative exposure to steroids. Azathioprine and MMF are often considered first-line therapies for PV with good improvement. Rituximab is beneficial in patients who have poorly controlled disease despite high-dose steroids or steroid-sparing agents (or both) or are contra-indicated for receiving steroids. IVIg in short-term studies is effective for recalcitrant cases but its duration of treatment needs further investigation.

There is no doubt that further research with larger RCTs is required. As more studies incorporate the definitions of disease and therapeutic end-points of the recent consensus statement, it is hoped that valuable and meaningful meta-analyses will provide more definitive answers.

\section{Abbreviations}

Dsg, desmoglein; IVIg, intravenous immunoglobulin; MMF, mycophenolate mofetil; PF, pemphigus foliaceus; PV, pemphigus vulgaris; RCT, randomized controlled trial.

\section{Disclosures}

The authors declare that they have no disclosures.

\section{References}

I. Aboobaker J, Morar N, Ramdial PK, Hammond MG: Pemphigus in South Africa. Int J Dermatol 200I, 40: II5-9.

2. Mahe A, Flageul B, Cisse I, Keita S, Bobin P: Pemphigus in Mali: a study of 30 cases. Br J Dermatol 1996, I34: I |4-9.

3. Crosby DL, Diaz LA: Endemic pemphigus foliaceus. Fogo selvagem. Dermatol Clin 1993, I I:453-62.

4. Bystryn JC, Steinman NM: The adjuvant therapy of pemphigus. An update. Arch Dermatol 1996, I32:203-12.

5. Martin LK, Murrell DF: Treatment of pemphigus: the need for more evidence. Arch Dermatol 2008, I44:100-I.

6. Martin LK, Werth V, Villanueva E, Segall J, Murrell DF: Interventions for pemphigus vulgaris and pemphigus foliaceus. Cochrane Database Syst Rev 2009:CD006263.

7. Murrell DF, Dick S, Ahmed AR, Amagai M, Barnadas MA, Borradori L, Bystryn JC, Cianchini G, Diaz L, Fivenson D, Hall R, Harman KE, Hashimoto T, Hertl M, Hunzelmann N, Iranzo P, Joly P, Jonkman MF, Kitajima Y, Korman NJ, Martin LK, Mimouni D, Pandya AG, Payne AS, Rubenstein D, Shimizu H, Sinha AA, Sirois D, Zillikens D, Werth VP: Consensus statement on definitions of disease, end points, and therapeutic response for pemphigus. J Am Acad Dermatol 2008, 58: 1043-6.

8. Ratnam KV, Phay KL, Tan CK: Pemphigus therapy with oral prednisolone regimens. A 5-year study. Int J Dermatol 1990, 29:363-7.

\section{FlOOOPrime}

RECOMMENDED

9. Werth VP, Fivenson D, Pandya AG, Chen D, Rico MJ, Albrecht J, Jacobus D: Multicenter randomized, double-blind, placebocontrolled, clinical trial of dapsone as a glucocorticoid-sparing agent in maintenance-phase pemphigus vulgaris. Arch Dermatol 2008, 144:25-32.

FlOOOPrime
RECOMMENDED

10. Chams-Davatchi C, Mortazavizadeh A, Daneshpazhooh M, Davatchi F, Balighi K, Esmaili N, Akhyani M, Hallaji Z, Seirafi H, Mortazavi H: Randomized double blind trial of prednisolone and azathioprine, vs. prednisolone and placebo, in the treatment of pemphigus vulgaris. J Eur Acad Dermatol Venereol 2012, 27: 1285-92.

\section{FlOOOPrime}

II. Chams-Davatchi C, Esmaili N, Daneshpazhooh M, Valikhani M, Balighi K, Hallaji Z, Barzegari M, Akhyani M, Ghodsi SZ, Seirafi H, Nazemi MJ, Mortazavi H, Mirshams-Shahshahani M: Randomized controlled open-label trial of four treatment regimens for pemphigus vulgaris. J Am Acad Dermatol 2007, 57:622-8. 
12. Beissert S, Mimouni D, Kanwar AJ, Solomons N, Kalia V, Anhalt G]: Treating Pemphigus Vulgaris with Prednisone and Mycophenolate Mofetil: A Multicenter, Randomized, PlaceboControlled Trial. J Invest Dermatol 2010, 130:204I-8.

\section{FlOOOPRime}

13. Beissert S, Werfel T, Frieling U, Böhm M, Sticherling M, Stadler R, Zillikens D, Rzany B, Hunzelmann N, Meurer M, Gollnick $H$, Ruzicka T, Pillekamp H, Junghans V, Luger TA: A comparison of oral methylprednisolone plus azathioprine or mycophenolate mofetil for the treatment of pemphigus. Arch Dermatol 2006, 142: 1447-54.

\section{FlOOOPRime
RECOMMENDED}

14. Mimouni D, Anhalt GJ, Cummins DL, Kouba DJ, Thorne JE, Nousari HC: Treatment of pemphigus vulgaris and pemphigus foliaceus with mycophenolate mofetil. Arch Dermatol 2003, 139:739-42.

15. loannides D, Apalla Z, Lazaridou E, Rigopoulos D: Evaluation of mycophenolate mofetil as a steroid-sparing agent in pemphigus: a randomized, prospective study. J Eur Acad Dermatol Venereol 2012, 26:855-60

\section{FlOOOPrime}

\section{RECOMMENDED}

16. Chrysomallis F, loannides D, Teknetzis A, Panagiotidou D, Minas A: Treatment of oral pemphigus vulgaris. Int J Dermatol 1994, 33:803-7.

\section{FlOOOPrime RECOMMENDED}

17. loannides D, Chrysomallis F, Bystryn JC: Ineffectiveness of cyclosporine as an adjuvant to corticosteroids in the treatment of pemphigus. Arch Dermatol 2000, 136:868-72.

\section{FIOOOPrime}

18. Amagai M, Ikeda S, Shimizu H, lizuka H, Hanada K, Aiba S, Kaneko F, Izaki S, Tamaki K, Ikezawa Z, Takigawa M, Seishima M, Tanaka T, Miyachi Y, Katayama I, Horiguchi Y, Miyagawa S, Furukawa F, Iwatsuki K, Hide M, Tokura Y, Furue M, Hashimoto T, Ihn H, Fujiwara S, Nishikawa T, Ogawa H, Kitajima Y, Hashimoto K; Pemphigus Study Group: A randomized double-blind trial of intravenous immunoglobulin for pemphigus. J Am Acad Dermatol 2009, 60: 595-603.

\section{FlOOOPrime RECOMMENDED}

19. Arnold DF, Burton J, Shine B, Wojnarowska F, Misbah SA: An 'n-of-I' placebo-controlled crossover trial of intravenous immunoglobulin as adjuvant therapy in refractory pemphigus vulgaris. Br J Dermatol 2009, 160:1098-102.

\section{FlOOOPrime} RECOMMENDED
20. Arin MJ, Engert A, Krieg T, Hunzelmann N: Anti-CD20 monoclonal antibody (rituximab) in the treatment of pemphigus. $\mathrm{Br} J$ Dermatol 2005, 153:620-5.

\section{FlOOOPrime}

\section{RECOMMENDED}

21. Ahmed AR, Spigelman Z, Cavacini LA, Posner MR: Treatment of pemphigus vulgaris with rituximab and intravenous immune globulin. N EnglJ Med 2006, 355: I772-9.

\section{FlOOOPrime}

\section{RECOMMENDED}

22. Joly $P$, Mouquet $H$, Roujeau JC, D'Incan $M$, Gilbert $D$, Jacquot $S$, Gougeon ML, Bedane C, Muller R, Dreno B, Doutre MS, Delaporte E, Pauwels C, Franck N, Caux F, Picard C, Tancrede-Bohin E, Bernard P, Tron F, Hertl M, Musette P: A single cycle of rituximab for the treatment of severe pemphigus. N Engl J Med 2007, 357:545-52.

\section{FlOOOPrime}

RECOMMENDED

23. Sharma VK, Khandpur S: Evaluation of cyclophosphamide pulse therapy as an adjuvant to oral corticosteroid in the management of pemphigus vulgaris. Clin Exp Dermatol 2013, 38:659-64.

\section{FlOOOPrime} RECOMMENDED

24. Rose E, Wever S, Zilliken D, Linse R, Haustein UF, Brocker EB: Intravenous dexamethasone-cyclophosphamide pulse therapy in comparison with oral methylprednisolone-azathioprine therapy in patients with pemphigus: results of a multicenter prospectively randomized study. J Dtsch Dermatol Ges 2005, 3:200-6.

\section{FlOOOPrime}

25. O'Connell TX, Berenbaum MC: Cardiac and pulmonary effects of high doses of cyclophosphamide and isophosphamide. Cancer Res 1974, 34:1586-91.

\section{FlOOOPrime}

RECOMMENDED

26. Chryssomallis F, Dimitriades A, Chaidemenos GC, Panagiotides D, Karakatsanis G: Steroid-pulse therapy in pemphigus vulgaris long term follow-up. Int J Dermatol 1995, 34:438-42.

\section{FlOOOPrime}

RECOMMENDED

27. Colliou N, Picard D, Caillot F, Calbo S, Le Corre S, Lim A, Lemercier B, Le Mauff B, Maho-Vaillant M, Jacquot S, Bedane C, Bernard P, Caux F, Prost C, Delaporte E, Doutre MS, Dreno B, Franck N, Ingen-Housz-Oro S, Chosidow O, Pauwels C, Picard C, Roujeau JC, Sigal M, Tancrede-Bohin E, Templier I, Eming R, Hertl M, D'Incan $M$, Joly $P$, et al:: Long-term remissions of severe pemphigus after rituximab therapy are associated with prolonged failure of desmoglein B cell response. Sci Transl Med 2013, 5:175-130.

\section{FlOOOPrime}

